\title{
EVALUASI PROGRAM JAMINAN KESEHATAN NASIONAL (STUDI EVALUASI PROGRAM BPJS KESEHATAN PADA TENAGA KERJA DI SURABAYA TAHUN 2014-2016)
}

\begin{abstract}
Aninda Yusmiati Dewi ${ }^{1}$, Sjamsiar Sjamsudin ${ }^{2}$ dan Lely Indah Mindarti ${ }^{3}$
\end{abstract}
\begin{abstract}
Law Number 24 Year 2011 on Social Security Administering Institution functions as guidance in the implementation of social insurance. One of the membership requirement mentioned in the act is the workforce (PPU). To obtain the Health Insurance, the Manpower (PPU) is required to pay a contribution of 5\% of the Regional Minimum Wage under the terms of 4\% of employers and $1 \%$ of Labor. Nevertheless the expected health services have not been achieved yet. The needs for evaluating National Health Insurance program were to assess the extent of program effectiveness, service improvement and membership expansion. This research focused on input, process, and output of JKN Program implementation operated by BPJS Health KCU Surabaya. The research used descriptive qualitative method. The results showed that the assessment of the JKN program implementation both in terms of input, process and output has been implemented quite well.
\end{abstract}

Keywords: Policy Evaluation, National Health Insurance Program, BPJS on Health Surabaya, Manpower

\section{ABSTRAK}

UU Nomor 24 Tahun 2011 tentang Badan Penyelenggara Jaminan Sosial adalah sebagai acuan dalam pelaksanaan jaminan sosial. Salah satu kepesertaan yang disebutkan dalam Undang-Undang tersebut adalah tenaga kerja (PPU). Untuk mendapatkan jaminan kesehatan tersebut Tenaga Kerja (PPU) diwajibkan membayar iuran sebesar 5\% dari Upah Minimum Regional dengan ketentuan $4 \%$ pemberi kerja dan 1\% tenaga kerja. Sedangkan pelayanan kesehatan yang diharapkan belum tercapai. Perlunya evaluasi program Jaminan Kesehatan Nasional untuk menilai sejauh mana efektivitas program, peningkatan pelayanan dan perluasan kepesertaan. Fokus penelitian ini adalah pada input, proses, dan output dari implementasi program JKN yang dilaksanakan oleh BPJS Kesehatan KCU Surabaya. Penelitian menggunakan metode kualitatif deskriptif. Hasil penelitian menunjukkan bahwa penilaian terhadap implementasi program JKN baik itu dari segi input, proses, dan output telah dilaksanakan cukup baik.

Kata Kunci: Evaluasi Kebijakan, Program Jaminan Kesehatan Nasional, BPJS Kesehatan Kota Surabaya, Tenaga Kerja.

1,2,3 Administrasi Publik, Fakultas Ilmu Administrasi, Universitas Brawijaya. email: aneendadewi@gmail.com 


\section{PENDAHULUAN}

Kebijakan publik (public policy) sebenarnya menjadi realitas sosial sejak manusia menyadari bahwa mereka memiliki tujuan hidup yang sama disamping variasi kepentingan yang ada. Pengertian dasar kebijakan publik menurut Parson (1997, h.21) adalah sebagai perwujudan keinginan dari para sarjana sosial untuk memecahkan masalah-masalah sosial di lapangan (close the gap between knowledge and policy). Pada sudut pandang lain Abdul Wahab (2004, h.12) mengatakan bahwa istilah 'kebijakan' ini penggunaannya sering dipertukarkan dengan istilah-istilah lain seperti tujuan (goals) program, keputusan, undang-undang, ketentuan-ketentuan, standar, proposal dan grand design.

Kesehatan adalah salah satu hak asasi manusia sehingga kesehatan merupakan kewajiban pemerintah kepada warga negaranya terutama terhadap warga negara yang kurang memiliki akses terhadap pelayanan kesehatan yang bermutu karena pengaruh ketidakmampuan secara ekonomi. Pada tahun 2000, untuk pertama kalinya katakata "kesehatan" tercantum dalam UUD 1945 pada pasal 28H yang merupakan hasil amandemen tahun 2000 “....setiap penduduk berhak atas pelayanan kesehatan". Hal ini tentu saja merupakan jaminan hak-hak kesehatan bagi seluruh rakyat Indonesia sesuai dengan deklarasi Hak Asasi Manusia oleh PBB pada tahun 1947.

Undang-Undang Nomor 40 tahun 2004 tentang Sistem Jaminan Sosial Nasional merupakan kebijakan baru di bidang jaminan sosial di Indonesia yang bertujuan untuk menggantikan programprogram jaminan sosial yang ada sebelumnya seperti ASKES, JAMSOSTEK, TASPEN, DAN ASABRI dan mencakup seluruh penduduk. Sebagai program baru tentu saja diperlukan analisis yang baik agar pada tataran implementasinya tujuan yang diharapkan dapat tercapai secara optimal yang pada gilirannya akan meningkatkan kesejahteraan penduduk termasuk di bidang kesehatan melalui Jaminan Kesehatan Nasional (JKN).

Program JKN yang digulirkan oleh pemerintah pada 1 Januari 2014 dengan tujuan untuk menyejahterakan masyarakat dalam bidang kesehatan seperti memiliki dua sisi mata uang. Salah satu sisi memberikan kemudahan bagi masyarakat untuk merasakan jaminan kesehatan, namun di sisi lain memberikan beban karena jaminan kesehatan yang ada tidak diberikan secara gratis, ada harga yang 
dibayarkan untuk mendapatkan pelayanan kesehatan. Pemerataan setiap warga negara seperti UU Nomor 36 Tahun 2009 tentang Kesehatan ditegaskan bahwa pembangunan kesehatan diselenggarakan berdasarkan asas manfaat, keseimbangan, perlindungan, penghormatan terhadap hak dan kewajiban, keadilan, perikemanusiaan, gender dan nondiskriminatif.

Faktanya di dalam Perpres No. 23/2013 tentang JKN, beberapa pasal bersifat diskriminatif, tidak menghormati hak-hak kesehatan rakyat terutama masyarakat miskin, serta tidak mepertimbangkan situasi dan kondisi fasilitas pelayanan kesehatan di Indonesia saat ini. Hampir 4 (empat) tahun pelaksanaan program Jaminan Kesehatan Nasional (JKN). Sebagai penyelenggara tunggal, Badan Penyelenggaraan Jaminan Sosial (BPJS) diupayakan dapat mengakomodir pelaksanaan program JKN ini secara sistematis demi memenuhi amanat undang-undang. Namun tidak bisa dipungkiri berbagai kelemahan masih terjadi dalam operasionalnya. "Usia" BPJS yang masih muda tentu tidak bisa dijadikan alasan mengingat BPJS Kesehatan adalah transformasi dari badan usaha yang sebelumnya juga bergerak di bidang asuransi kesehatan.
Kenaikan iuran yang dibebankan kepada masyarakat juga telah menjadi polemik tersendiri. Sesuai dengan Peraturan Presiden Nomor 19 Tahun 2016 tentang Perubahan Kedua Atas Peraturan Presiden Nomor 12 Tahun 2013 tentang Jaminan Kesehatan. Sehingga terhitung mulai 1 April 2016 iuran peserta Jaminan Kesehatan Nasional baik untuk masyarakat pekerja penerima upah dan peserta pekerja bukan penerima upah mengalami kenaikan. Kenaikan tersebut beralasan untuk menekan deficit klaim pembayaran, selain itu harapan untuk dapat meningkatkan mutu pelayanan.

Pekerja Penerima Upah (PPU) menjadi salah satu pihak yang terkena dampak dari sistem Jaminan Kesehatan Nasional yang berasaskan gotong royong. Persentase yang dibebankan kepada PPU disesuaikan dengan upah yang diterima, hal tersebut diatur dalam Peraturan Presiden Nomor 19 tahun 2016. Perusahaan terbebani harus mendaftarkan seluruh pekerja untuk menjadi peserta Jaminan Kesehatan Nasional. Hal tersebut tertulis jelas dalam Undang-Undang Nomor 24 Tahun 2011 tentang BPJS Kesehatan yang menyebutkan Pemberi Kerja secara bertahap wajib mendaftarkan dirinya dan pekerjanya sebagai peserta kepada BPJS sesuai dengan Program 
Jaminan Sosial yang diikuti. Belum terselesaikan permasalahan pelayanan kesehatan, Jaminan Kesehatan Nasional yang diselenggarakan oleh BPJS Kesehatan secara teknis telah berganti nama menjadi JKN-KIS (Jaminan Kesehatan Nasional-Kartu Indonesia Sehat). Tetapi secara signifikan belum dirasakan adanya peningkatan pelayanan kesehatan dari program JKN-KIS. Secara teknis, kartu yang digunakan oleh peserta yang berubah, dengan alasan banyaknya penyalahgunaan yang terjadi di lapangan seperti pemalsuan kartu dan kode. Selain itu, dari BPJS Kesehatan sendiri hanya memberikan jawaban mengikuti peraturan pemerintah.

Seiring dengan kenaikan iuran, pelayanan kesehatan yang diharapkan dapat terpenuhi menjadi sebuah tujuan dari adanya Jaminan Kesehatan Nasional ini. Terlebih sejak transformasi jaminan kesehatan untuk pekerja Penerima Upah yang telah dilebur menjadi satu menjadi BPJS (Badan Penyelenggara Jaminan Sosial). Perlu diketahui bahwa bagi pekerja penerima upah (PPU) dibedakan menjadi 2 (dua) yaitu tenaga kerja swasta, BUMN, BUMD dan Pegawai yang berkerja di lembaga pemerintahan yang didalamnya terdiri dari PNS, Polri, TNI, pejabat negara dan pekerja pemerintah non PNS. Sebelumnya adalah bagian dari sistem asuransi kesehatan yang dibedakan, yaitu untuk pekerja pemerintah ditangani oleh PT. Askes dan untuk pekerja non pemerintah oleh PT. Jamsostek. Kelebihan dari sistem asuransi yang dibedakan adalah, tidak memerlukan perubahan sistem yang berbelit-belit dengan tujuan yang sama yaitu kesehatan dan kesejahteraan. Namun, kebijakan pemerintah yang mewajibkan untuk setiap warga negara Indonesia mengikuti jaminan kesehatan nasional menjadikan tujuan dari JKN ini sedikit "memaksa" bagi pemberi upah untuk dapat mengikuti program.

Manfaat yang didapat menjadi peserta BPJS Kesehatan untuk tenaga kerja antara lain yaitu, peserta yang telah didaftarkan oleh perusahaan dengan minimal UMR (Upah Minimum Regional) telah mendapatkan pelayanan fasilitas kesehatan tingkat kelas II (dua). Fasilitas kesehatan tersebut dapat digunakan dengan indikasi medis yang beberapa asuransi swasta mengecualikannya, dengan kata lain BPJS Kesehatan menanggung semua jenis penyakit, maupun persalinan (Permenkesnomor 28 tahun 2014) Kedua, iuran yang ditanggung oleh peserta PPU hanya $1 \%$ dari 5\%upah yang dilaporkan dan sudah 
mencakup 5 anggota keluarga dari peserta. Manfaat tersebut belum mampu menarik minat perusahaan untuk mendaftarkan tenaga kerja pada BPJS Kesehatan. Secara keseluruhan BPJS Telah merilis jumlah peserta per 13 Januari 2017 adalah sebanyak 172.620.296 (Seratus tujuh puluh dua juta enam ratus dua puluh ribu dua ratus Sembilan puluh enam jiwa). Jumlah tersebut terbagi dari $63 \%$ Peserta BPJS Kesehatan Penerima Bantuan Iuran (PBI) dan $24 \%$ merupakan peserta BPJS Kesehatan Pekerja Penerima Upah serta $13 \%$ merupakan peserta mandiri yang iurannya dibayar sendiri. Dari daftar tersebut, PPU swasta berjumlah 23.594.328 (dua puluh tiga juta lima ratus Sembilan puluh empat tiga ratus dua puluh delapan jiwa) (BPJS Online, diakses 20 Januari 2017). PPU swasta atau tenaga kerja di Surabaya yang sudah terdaftar di BPJS Kesehatan hanya $37,03 \%$ dari jumlah keseluruhan tenaga kerja. Jumlah tenaga kerja di Surabaya mencapai 1.475.989 orang, yang terdiri dari pekerja formal sebanyak 664.191 orang dan pekerja informal sebanyak 811.798 orang (Antaranews, Rabu 14 Desember 2016, diakses 20 Januari 2017).

Evaluasi menjadi penting ketika suatu tujuan (goal) dalam sebuah kebijakan belum terpenuhi. Evaluasi kebijakan dilakukan untuk menilai sejauh mana keefektifan kebijakan publik untuk dipertanggungjawabkan kepada publiknya dalam rangka mencapai tujuan yang telah ditetapkan. Oleh karena itu diperlukannya evaluasi implementasi kebijakan Jaminan Kesehatan Nasional oleh BPJS Kesehatan sebagai wujud perlindungan kesehatan tenaga kerja di Kota Surabaya. Evaluasi ini menggunakan pendekatan evaluasi formatif yang difokuskan pada (1) input yaitu sumber daya manusia dan dana, (2) Proses dalam hal ini adalah proses pencapaian tujuan BPJS Kesehatan dan (3) Output yang telah dicapai selama pelaksanaan program BPJS Kesehatan untuk tenaga kerja di Surabaya.

\section{METODE}

Penelitian ini termasuk evaluasi formatif dengan jenis evaluasi administratif, karena sesuai dengan program JKN, pelaksana program tersebut adalah BPJS Kesehatan, yang merupakan badan hukum yang dibentuk untuk menyelenggarakan program jaminan sosial (UU Nomor 24 Tahun 2011 Ayat 1). Metode yang digunakan adalah kualitatif deskriptif. Responden penelitian ini adalah 32 orang yang diambil dengan teknik Purposive Sampling, terdiri dari beberapa pegawai BPJS Kesehatan KCU Surabaya dan Perwakilan Badan Usaha 
yang berkepentingan. Fokus penelitian adalah evaluasi program jaminan kesehatan nasional meliputi input, proses, dan output. Serta menganalisis faktor pendukung dan penghambat dalam melaksanakan program Jaminan Kesehatan Nasional untuk tenaga kerja. Analisis data menggunakan teori triple loops, dengan tujuan untuk mendapatkan analisis mendalam tentang program jaminan kesehatan nasional.

\section{HASIL DAN PEMBAHASAN}

Evaluasi Program Jaminan Kesehatan Nasional untuk Tenaga Kerja Kota Surabaya di Kota Surabaya tahun 2014-2016

Program Jaminan Kesehatan Nasional telah berjalan mulai dari 1 Januari 2014 sampai dengan saat ini. Maka evaluasi yang dapat dilakukan adalah evaluasi proses. Secara tipe evaluasi proses digolongkan dalam evaluasi formatif. Evaluasi formatif dilakukan saat program masih belangsung dengan tujuan utamanya adalah untuk menyediakan informasi untuk improvisasi program serta sering digunakan untuk menilai manfaat dan kegunaan suatu bagian tertentu dari program (Fitzpatrick dkk, 2004, h.16). Evaluasi proses yang digunakan untuk mengevaluasi program
JKN dilihat dari unsur input (SDM dan Dana/Pembiayaan), proses dan output. Serta perlu diketahui faktor pendukung dan penghambat dari implementasi program JKN yang masih berlangsung sampai saat ini.

\section{Sumber Daya Manusia yang terlibat} dalam Implementasi Program JKN di Kota Surabaya

Sumber Daya Manusia pelaksana BPJS Kesehatan diatur dalam UndangUndang Nomor 24 Tahun 2011 Bab IV tentang Organ BPJS. Dalam Pasal 20 disebutkan bahwa Organ BPJS adalah dewan pengawas dan direksi. BPJS Kesehatan KCU Surabaya dibagi menjadi 2 (dua) kantor dengan alamat yang berbeda; (1) Di Kantor Dharmahusada dengan pembagian pelayanan untuk peserta PBPU (mandiri) dan PPU (PNS, TNI, Polri, veteran maupun pensiun) dan (2) Berada di Ruko Mega Galaxy Mall dengan pelayanan dikhususkan pada peserta PPU dari badan usaha. Kenyamanan kantor terjamin, ada 3 orang sekuriti untuk membantu resepsionist dalam memberikan informasi, mengamankan, dan menertibkan sistem antrian pada kantor pusat dan 1 (satu) orang dikantor cabang.

Salah satunya upaya untuk meningkatkan kualitas layanan adalah 
dengan mengatur kelembagaan dengan struktur organisasi. Struktur organisasi pada BPJS Kesehatan KCU Surabaya memiliki kepala kantor cabang dan membawahi 6 (enam) divisi dan bertanggung jawab langsung kepada kepala kabupaten/kota. Divisi yang terbagi menjadi 6 bagian saling terkait, meskipun berbeda tempat.

Kepegawaian di BPJS Kesehatan dari segi manajemen, terdiri dari level manajerial dan operasional. Untuk manajerial bertugas untuk memberikan pelayanan secara tidak langsung. Artinya mereka akan menangani special case dalam bentuk permasalahan yang lebih urgent bukan sebagai pemberi langsung pelayanan yang mengharuskan tatap muka secara teknis. Sebagian besar adalah pegawai perpindahan dari transformasi PT. Askes menjadi BPJS Kesehatan. Sebagian lagi adalah hasil rekruitmen karyawan yang dilakukan setelah BPJS Kesehatan terbentuk pada tahun 2014. Dan semakin berkembangnya jumlah kepesertaan BPJS Kesehatan merekrut tenaga PTT dengan sistem PKWT.

Penyampaian informasi yang diberikan adalah berdasarkan kualitas dari SDM yang ada. Ketika SDM menguasai informasi pada BPJS Kesehatan, maka reability-nya terpenuhi. Peserta badan usaha menilai bahwa pertanyaan yang diajukan kepada petugas FO dapat terpenuhi dengan baik. Namun, terkadang informasi tadi berkembang ketika menemukan permasalahan yang berbeda di lapangan. Jadi kualitas SDM pada BPJS Kesehatan KCU Surabaya telah diperhatikan dengan baik, dengan adanya struktur organisasi yang terarah, serta sistem rekruitmen yang professional, dengan komitmen memberikan pelayanan yang tebaik kepada peserta sehingga merekrut PTT dengan masa 1 tahun disesuaikan dengan kualitas yang telah diberikan kepada peserta BPJS Kesehatan.

Dana Program Jaminan Kesehatan Nasional

Kepesertaan kaitannya dengan dana yang didapat oleh BPJS Kesehatan, semakin banyak peserta maka dana yang dapat dimanfaatkan oleh BPJS Kesehatan semakin bertambah. Sesuai dengan laporan audit keuangan kenaikan pendapatan iuran tahun 2016 secara umum. Kenaikan pendapatan iuran secara signifikan dari tahun 2014 sampai dengan 2016.

1. Iuran Jaminan Kesehatan BPJS Kesehatan.

Iuran Jaminan Kesehatan adalah sejumlah uang yang dibayarkan secara teratur oleh Peserta, Pemberi Kerja, dan/atau 
Pemerintah untuk program jaminan kesehatan (pasal 16, perpres No. 19 tahun 2016 tentang perubahan kedua atas Perpres No. 12 Tahun 2013 Tentang Jaminan kesehatan).

Semua peserta wajib membayar iuran yang besarnya telah ditetapkan sesuai dengan perturan perundangundangan. Bagi peserta Pekerja Penerima Upah berdasarkan persentase dari upah atau suatu jumlah nominal tertentu. Setiap pemberi kerja wajin memungut iuran dari pekerjanya, menambahkan iuran peserta yang menjadi tanggung jawabnya, dan membayarkan iuran tersebut setiap bulan kepada BPJS Kesehatan secara berkala (Paling lambat tanggal 10 setiap bulan). Apabila tanggal 10 (sepuluh) jatuh pada hari libur maka iuran dibayarkan pada hari kerja berikutnya.

Sesuai dengan Perpres No. 19 Tahun 2017 tentang perubahan kedua atas Perpres No. 12 Tahun besaran iuran perbulan yang harus dibayar sesuai dengan jenis kepesertaan masing-masing dalam JKN adalah: (1) Iuran jaminan kesehatan bagi Peserta Pekerja Penerima Upah yang terdiri atas Pegawai Negeri Sipil, Anggota TNI, Anggota Polri, Pejabat Negara, dan Pegawai Pemerintah Non Pegawai Negeri yang dibayar melalui APBN/APBD sebesar 5\% (lima persen) dari Gaji atau Upah per bulan dibayar dengan ketentuan 3\% (tiga persen) dibayar oleh Pemberi Kerja dan 2\% (dua persen) dibayar oleh Peserta. (2) Iuran Jaminan Kesehatan bagi Peserta PPU selain Peserta diatas adalah sebesar 4,5\% (mulai tanggal 1 Juli 2015 sebesar 5\%) dari Gaji atau Upah per bulan dengan ketentuan, 4\% dibayar oleh Pemberi Kerja, 0,5\% dibayar oleh Peserta (mulai tanggal 1 Juli 2015 sebesar 1\%).

UMK di Kota Surabaya selalu mengalami kenaikan setiap tahun. Pada tahun 2014, UMK untuk pekerja adalah sebesar Rp.2.200.000 dan jumlah yang harus dibayarkan oleh badan usaha sebesar Rp.99.000, mengalami kenaikan hampir $25 \%$ menjadi Rp.2.710.000 dengan iuran yang harus dibayarkan per peserta PPU adalah Rp.121.950 dan terakhir pada tahun 2016, UMK menjadi Rp.3.045.000 dengan iuran perbulan yang harus dibayarkan sebersar Rp.152.250. Sesuai dengan perubahan persentase yang harus dikeluarkan oleh PPU dan badan usaha per 1 Juli 2016 menjadi 5\%. Dari iuran tersebut PPU mendapatkan pelayanan kesehatan rawat inap kelas 2 (dua).

Gaji/upah yang diterima oleh tenaga kerja itu adalah yang menjadi dasar pembayaran iuran untuk Pekerja Penerima 
Upah. Sehingga laporan yang diterima oleh BPJS Kesehatan seharusnya adalah laporan real dari Badan Usaha. Apabila Pekerja menerima lebih dari UMR termasuk tunjangan tetap lebih besar dari 2 kali Penghasilan Tidak Kena Pajak maka berhak untuk mendapatkan pelayanan kesehatan kelas satu. Peserta BPJS PPU Karyawan tidak bisa memilih kelas sesuai dengan yang diinginkan karena hak kelas sangat tergantung sekali pada besar kecilnya gaji yang bersangkutan atau golongan pangkat. Bisa saja hak atas kelas diupgrade misal dari kelas 2 menjadi kelas 1, namun gaji harus memenuhi.

Apabila dari segi gaji pekerja atau peserta PPU tidak terpenuhi, namun masih menginginkan untuk mendapatkan pelayanan kelas 1 (satu) maka disarankan untuk mendaftarkan kepesertaannya mutasi ke PBPU/mandiri. Jika peserta PBPU maka pembayaran iuran yang harus dibayarkan adalah perseorangan, bukan lagi seperti PPU dengan sejumlah iuran telah mengcover 5 anggota keluarga inti.

Jadi, pelayanan kesehatan yang didapat oleh peserta Pekerja Penerima Upah adalah sesuai dengan ketentuan kelas yang dibayarkan sesuai iuran, dan potongan iuran didapatkan dari gaji/upah yang dibayarkan setiap bulan dengan persentase masing-masing. Tidak ada pembatasan bagi badan usaha kecil yang masih belum mampu dalam membayar gaji kurang dari UMK jika badan usaha mampu menunjukkan surat penangguhan pembayaran upah sesuai UMK dari Gubernur kepada BPJS Kesehatan.

2. Pengelolaan Iuran Jaminan Kesehatan BPJS Kesehatan.

Iuran yang sudah disetorkan ke BPJS Kesehatan melalui rekanan yang telah ditunjuk oleh BPJS Kesehatan dikolektif dan langsung tersetor pada BPJS Kesehatan Pusat. Pengelolaan dana yang masuk pada BPJS Kesehatan itulah yang dimaksud dengan Dana Jaminan Sosial. Tidak ada dana yang terkolektif di tingkat kota maupun provinsi. Tetapi untuk berapa jumlah peserta yang telah membayar kantor cabang akan terverifikasi oleh kantor pusat.

Pembagian dana pada BPJS Kesehatan terbagi menjadi 2 (dua) dana Jaminan Sosial, yaitu: (1) untuk memberikan manfaat jaminan kesehatan kepada peserta, dan (2) dana operasional yang digunakan untuk kebutuhan operasional BPJS Kesehatan termasuk dalam gaji dan belanja pegawai. Sistem ini diartikan sebagai sistem pembayaran yang dilakukan oleh pihak ketiga atau pihak asuransi setelah pencari layanan 
kesehatan berobat. Sistem health insurance ini dapat berupa sistem kapitasi dan sistem Diagnose Related Group (DRG System). Sistem kapitasi merupakan metode pembayaran untuk jasa pelayanan kesehatan dimana PPK menerima sejumlah tetap penghasilan per peserta untuk pelayanan yang telah ditentukan per periode waktu. Pembayaran bagi PPK dengan sistem kapitasi adalah pembayaran yang dilakukan oleh suatu lembaga kepada PPK atas jasa pelayanan kesehatan dengan pembayaran di muka sejumlah dana sebesar perkalian anggota dengan satuan biaya (unit cost) tertentu. Peserta Penerima Upah yang menjadi peserta akan membayar iuran dimuka untuk memperoleh pelayanan kesehatan paripurna dan berjenjang dengan pelaynan tingkat pertama sebagai ujung tombak yang memenuhi kebutuhan utama kesehatan dengan mutu terjaga dan biaya terjangkau.

Kelemahan dari sistem health insurance adalah dapat terjadinya underutilization dimana dapat terjadi penurunan kualitas dan fasilitas yang diberikan kepada pasien untuk memperoleh keuntungan sebesarbesarnya, selain itu jika peserta tidak banyak yang bergabung dalam sistem ini maka resiko kerugian tidak dapat dihindarkan. Namun dibalik kelemahan, terdapat kelebihan sistem ini berupa PPK data mendapat jaminan adanya pasien (captive market), mendapat kepastian dana dan di tiap awal periode waktu tertentu, PPK taat prosedur sehingga mengurangi terjadinya multidrug dan multidiagnose. Sistem ini akan membuat PPK lebih kearah preventif dan promotif kesehatan.

3. Sanksi Iuran Jaminan Kesehatan BPJS Kesehatan.

Badan usaha maupun pemberi kerja secara bertahap wajib mendaftarkan dirinya dan pekerjanya sebagai peserta kepada BPJS sesuai dengan program Jaminan Sosial yang diikuti (pasal 15 ayat 1). Sanksi yang dikenakan bagi pemberi kerja yang tidak melaksanakan ketentuan sebagaimana dalam ayat 15 ayat 1 akan terkena sanksi administratif, berupa teguran tertulis, denda, dan/atau tidak mendapatkan pelayanan publik tertentu.

Adanya dua macam sanksi yang diterapkan oleh BPJS Kesehatan KCU Surabaya sesuai dengan bidang yang menanganinya. Jika pemberi kerja tidak sesuai dengan 3 (tiga) objek kepatuhannya, maka akan dikenakan sanksi administratif. Pemberian sanksi pembayaran iuran dimulai dari keterlambatan pembayaran iuran sampai 
dengan tidak membayar iuran sama sekali oleh badan usaha. Tenaga kerja setiap bulan akan dipotongkan dari upah yang diterimanya dikalikan persentase yang sudah diatur dalam UU No 24 Tahun 2011. Apabila pemberi kerja menyalahi aturan tersebut, pekerja dapat melaporkan kepada BPJS Kesehatan atau kepolisian karena ketidakadilan dalam pungutan pembayaran iuran.

Selain penegasan dalam adanya sanksi BPJS Kesehatan juga menghitung kelebihan dan kekurangan iuran JKN sesuai dengan gaji atau upah peserta. Dalam hal ini terjadi kelebihan dan kekurangan pembayaran iuran. BPJS Kesehatan memberitahukan secara tertulis kepada Pemberi Kerja dan/atau Peserta paling lambat 14 hari kerja sejak diterimanya iuran. Kelebihan dan kekurangan pembayaran iuran diperhitungkan dengan pembayaran iuran bulan berikutnya.

\section{Proses Implementasi BPJS Kesehatan dari tahun 2014-2016}

1. Perluasan Kepesertaan untuk Peserta Penerima Upah Untuk Tenaga Kerja Swasta.

Kepesertaan dalam Program Jaminan Kesehatan Nasional dijelaskan dalam Peraturan Presiden Nomor 19 Tahun 2016 tentang perubahan kedua atas
Peraturan Presiden Nomor 12 Tahun 2013 Tentang Jaminan Kesehatan. Kepesertaan Jaminan Kesehatan bersifat wajib dan mencakup seluruh penduduk Indonesia. Kepesertaan Jaminan kesehatan Nasional dilakukan secara bertahap yaitu tahap pertama mulai 1 Januari 2014 hingga mencakup seluruh penduduk Indonesia paling lambat 1 Januari 2019.

Jumlah BU yang telah bergabung menjadi peserta JKN mencapai 187.083 BU se-Indonesia, sumber dari BPJS Kesehatan menyebutkan dengan jumlah BU terbanyak berasal dari Jakarta (55.072 BU), Surabaya (23.319 BU) dan Semarang (21.217 BU). Memperoleh jaminan kesehatan adalah hak pekerja yang tidak boleh ditunda, apalagi baru dipenuhi ketika yang bersangkutan sakit atau membutuhkan pelayanan. Terlebih, sustainibilitas program JKN yang dikelola BPJS Kesehatan sangat bergantung kepada iuran peserta yang sehat membayar biaya pelayanan kesehatan peserta yang sakit. Untuk mendukung perluasan kepersertaan PPU, diperlukan optimalisasi kepatuhan melalui sinergi seluruh instansi terkait dalam menegakkan kepatuhan. Pada sisi yang lain, untuk meningkatkan kepuasan kepuasan peserta, dilakukan pula intensifikasi sarana dan prasana fasilitas kesehatann yang sudah 
tersedia maupun penambahan fasilitas kesehatan RS. Inovasi suara pelanggan, customer service timer index dan dashboard RS merupakan wujud komitmen BPJS Kesehatan untuk meningkatkan kepuasan peserta.

Peserta Badan Usaha dapat memilih program $\mathrm{CoB}$ sebagai jaminan kesehatan dan memberikan kenyaman bagi pekerja. Untuk saat ini strategi BPJS Kesehatan KCU Surabaya adalah mejaring kepesertaan melalui kerja sama dengan badan perijinan (PTSP) serta sosialisasi yang bekerja sama dengan Disnaker, dan ARO untuk meningkatkan jumlah kepesertaan dari badan usaha. Mengingat badan usaha di Surabaya semakin bertambah dengan semakin berkembangnya ekonomi.

2. Pelayanan Peserta Penerima Upah Untuk Tenaga Kerja Swasta.

Pelayanan kesehatan berubah, dari jaminan pemeliharaan kesehatan yang pada awalnya menggunakan sistem reinbursment sekarang menggunakan sistem kapitasi sesuai dengan fasilitas kesehatan yang dipilih oleh pekerja. Pekerja cukup menunjukkan kartu BPJS Kesehatan di fasilitas kesehatan yang ditunjuk dan tanpa mengeluarkan biaya sedikitpun.
Pelayanan kesehatan pada BPJS Kesehatan terdiri dari pelayanan kesehatan fasilitas kesehatan tingkat pertama (FKTP) dan Fasilitas Kesehatan Tingkat Lanjutan (FKTL). FKTP terdiri dari puskesmas, dokter pribadi, klinik pratama dengan menggunakan sistem pembiayaan kapitasi. Sedangkan untuk FKTL terdiri dari Rumah Sakit Daerah dan Swasta yang bekerja sama menggunakan sistem INA CBGs. Jadi perubahan sistem pembiayaan berpengaruh pada sistem pelayanan yang diberikan oleh fasilitas kesehatan.

Pelayanan kesehatan yang awalnya menggunakan sistem fee for service (biaya untuk mendapatkan pelayanan) sehingga tenaga kerja yang ingin berobat dan mendapatkan pelayanan yang baik, maka dia harus membayar mahal. Dan sekarang pelayanan kesehatan menggunakan sistem kapitasi dan INA CBGs.

Perubahan paradigma dalam pola pelayanan BPJS Kesehatan bahwa dengan menggunakan sistem kapitasi akan menekan seseorang untuk tidak lagi banyak berobat. Tapi faskes tingkat pertama berperan dalam pemenuhan kesehatan bagi tenaga kerja. Jadi paradigmanya sekarang berbeda jika dulu semakin banyak yang sakit jadi faskes dan 
dokter dapat banyak uang. Sekarang paradigmanya dirubah pencegahan dan upaya preventif.

Untuk mendapatkan pertanggungan dari JKN, peserta tetap harus menerapkan prosedur yang berlaku, termasuk pelayanan berjenjang. Peserta harus membawa surat rujukan primer yang bekerja sama dengan BPJS Kesehatan. Di bawah ini adalah matrik koordinasi manfaat JKN.BPJS kesehatan menjamin biaya pengobatan seuai dengan biaya INA CBGs di rumah sakit. Sedangkan asuransi kesehatan tambahan akan menanggung selisih biaya dari pengobatan tersebut. Selanjutnya asuransi kesehatan tambahan akan mengajukan klaim ke BPJS Kesehatan untuk menagihkan biaya yang menjadi kewajibannya.

Hasil Implementasi Program JKN untuk Tenaga Kerja di Kota Surabaya

Mengacu pada WHO memberikan pedoman sebagai berikut, Pertama, seberapa besar persentase penduduk yang dijamin, kedua adalah seberapa lengkap pelayanan yang dijamin, dan ketiga seberapa besar proporsi biaya langsung yang masih ditanggung. Karena fokusnya adalah program JKN untuk tenaga kerja maka sebagai ukuran kinerja adalah pertama, seberapa besar jumlah kepesertaan tenaga kerja di BPJS kesehatan mulai dari tahun 2014 sampai dengan 2016. Kedua, seberapa lengkap pelayanan yang dijamin untuk tenaga kerja dan ketiga, seberapa besar proporsi biaya langsung yang masih ditanggung oleh tenaga kerja untuk mendapatkan pelayanan kesehatan.

1. Jumlah Kepesertaan Tenaga Kerja di BPJS Kesehatan.

BPJS KCU Kota Surabaya telah memberikan pelayanan dari tahun 2014 sampai dengan saat ini. Kepesertaan yang ditangani merupakan seluruh wilayah kota Surabaya. Dalam hal ini terbagi menjadi 31 kecamatan. Jumlah badan usaha mengalami fluktuatif, pada tahun 2014 adalah masa dalam transformasi Jaminan Kesehatan untuk tenaga kerja dari PT Jamsostek menjadi BPJS Kesehatan. Total jumlah badan usaha pada tahun 2014 adalah 4221 badan usaha yang tersebar di 31 kecamatan di Surabaya. Badan Usaha yang aktif dalam melakukan pembayaran, dan pendaftaran kepesertaan tenaga kerja dan aktifitas lain sebesar 3122 dan yang tidak aktif mencapai 1099. Pada tahun 2015 jumlah badan usaha mengalami penurunan yaitu 1985 dengan total keseluruhan badan usaha yang aktif sebanyak 1985 dan tidak aktif 160 badan usaha. Pada tahun 2016 kembali 
meningkat dengan total badan usaha sebesar 7846 dengan aktif dalam kepesertaan sebesar 2066 dan kenonaktifan hingga mencapai angka 5780 badan usaha.

Faktanya pertambahan jumlah BU aktif tidak diikuti dengan jumlah tenaga kerja, karena dimungkinkan adanya mutasi tenaga kerja yang keluar, atau bisa juga karena badan usaha belum mendaftarkan tenaga kerja baru di BPJS Kesehatan KCU Surabaya. Oleh karena itu, BPJS Kesehatatan telah mempermudah pendaftaran kepesertaan untuk badan usaha seperti cara offline yakni dengan mendatangi kantor BPJS Kesehatan KCU Surabaya, dan cara online melalui mendaftarkan dengan kolom 37 yang telah diisi dan dilengkapi persyaratannya. Dengan cara demikian BPJS Kesehatan berharap mampu meningkatkan jumlah kepesertaan bagi tenaga kerja, sehingga tujuan dari BPJS Kesehatan dapat tercapai.

2. Pelayanan kesehatan yang dijamin untuk tenaga kerja.

Pelayanan kesehatan untuk tenaga kerja tidak dibedakan dengan peserta yang lain. Menurut Peraturan Presiden Nomor 19 Tahun 2016 adalah pelayanan kesehatan yang dijamin terdiri atas pelayanan kesehatan tingkat pertama
(FKTP) dan pelayanan kesehatan tingkat rujukan tingkat lanjutan (FKTRL).

Keseluruhan jumlah adalah terdapat 63 Puskesmas di Surabaya yang tersebar dari 31 kecamatan. Selain pengembangan jumlah FKTP, BPJS Kesehatan meningkatkan kerja sama untuk FKTRL. Jumlah FKTRL di Kota Surabaya berupa rumah sakit sebagai rujukan bagi tenaga kerja yang perlu ditangani secara spesialistik secara medis. Beberapa badan usaha yang berhasil diwawancarai sebagai perwakilan tenaga kerja menjelaskan bahwa, tenaga kerja masih mengeluhkan sistem pelayanan BPJS Kesehatan pada tingkat pelayanan fasilitas kesehatan. Karena generalisasi pelayanan pada semua lini masyarakat, maka antrian pelayanan kesehatan tidak dapat dihindari. Bagi peserta BPJS Kesehatan yang ingin menggunakan kartu JKN di fasilitas kesehatan harus meluangkan waktu lebih banyak untuk mengantri dan mendapatkan pelayanan.

3. Biaya langsung yang masih ditanggung oleh tenaga kerja untuk mendapatkan pelayanan kesehatan.

Biaya pelayanan yang dicover BPJS Kesehatan di fasilitas tingkat pertama adalah biaya kapitasi maksimal di puskesmas. Dari hasil wawancara dijelaskan bahwa dalam setiap peserta 
JKN yang telah membayar iuran telah mendapatkan manfaat pelayanan kesehatan dari fasilitas kesehatan tingkat pertama. Pembiayaan tersebut dilakukan oleh BPJS Kesehatan dengan sistem kapitasi yang disesuaikan dengan jumlah kepesertaan pada faskes. Kapitasi tersebut diatur dalam Permenkes Nomor 21 Tahun 2016 sebagai revisi Permenkes No 19 tahun 2014. Iuran yang diperoleh BPJS Kesehatan dibayarkan untuk biaya kapitasi pada faskes tingkat pertama dan pelayanan tingkat lanjutan/faskes II.

Pelayanan kesehatan yang dicover oleh BPJS Kesehatan dapat dimanfaatkan oleh semua peserta PPU yang telah membayar iuran setiap bulan. Peserta tidak perlu lagi mengeluarkan biaya untuk mendapatkan pelayanan kesehatan dengan ketentuan sesuai dengan prosedur BPJS Kesehatan dan sesuai dengan indikasi medis sesuai dengan kelas perawatannya. Jika pekerja ingin meningkatkan pelayanan dapat berkoordinasi dengan FKTP dan FKTRL untuk meningkatkan kelas rawat inap dan membayarkan selisih diakhir perawatan yang telah dilakukan.

\section{Faktor Pendukung}

1. Kualitas sumber daya manusia (SDM) yang berkompeten.

Widodo (dalam Kharis, 2010, h.8) sumber daya manusia dapat dikatakan berkualitas manakala mereka mempunyai kemampuan untuk melaksanakan kewenangan dan tanggung jawab yang diberikan kepadanya. Para pegawai BPJS terbagi dari beberapa divisi dan masingmasing divisi telah melaksanakan tugas dan fungsi sesuai dengan SOP.

Rekruitmen pegawai dilakukan secara professional. Penempatan pegawai dilakukan sesuai dengan latar pendidikan yang sesuai. Menurut Siagian (2009, h.163) profesionalisme adalah keandalan dan keahlian dalam pelaksanaan tugas sehingga terlaksana dengan mutu tinggi, waktu yang tepat, cermat, dan dengan prosedur yang mudah dipahami.

Selain itu, kompetensi masingmasing pegawai telah diperhitungkan untuk pelaksanaan pelayanan pada BPJS Kesehatan. Untuk tenaga PTT dengan sistem PKWT juga melalui sistem rekrutmen yang professional, dan terdapat evaluasi dalam kinerja para PTT setiap tahunnya.Secara eksternal yaitu dari hubungan kerja sama antar lembaga BPJS kesehatan dengan fasilitas kesehatan. SDM mencakup pelayanan kesehatan oleh fasilitas kesehatan seperti tenaga medis dan tenaga farmasi.

Tenaga medis seperti ijin dokter pribadi yang akan bekerja sama dengan BPJS Kesehatan, harus melalui proses 
kredensialing. Hal tersebut telah menjadi alasan utama sebagai perintah UndangUndang Nomor 40 Tahun 2004 tentang Sistem Jaminan Sosial Nasional dan peraturan pelaksanaannya, serta mewujudkan jaminan tersedianya layanan dan mutu yang dipercaya oleh peserta.

BU juga menjelaskan bahwa, setiap informasi yang dibutuhkan kepada BPJS Kesehatan KCU Surabaya telah dijawab sesuai dengan pertanyaan yang diberikan. Artinya tenaga kerja dapat menerima informasi secara langsung ketika datang di kantor BPJS Kesehatan untuk badan usaha.

2. Sistem Informasi Manajemen BPJS Kesehatan yang baik.

BPJS telah melaksanakan sistem informasi manajemen berbasis komputer dan online. Sistem database kepesertaan menggunakan sudah terhubung sistem dispendukcapil dengan Nomor Induk Kependudukan KTP, dan Nomor KK yang menjadi dasar dalam pendaftaran kepesertaan.

BPJS Kesehatan telah memiliki sistem informasi manajemen yang baik yaitu mengubungkan sistem input data kepesertaan dengan data dispendukcapil secara lengkap. Sistem pendaftaran oleh badan usaha pun dibuat secara online dengan menggunakan sistem e-dabu.
Sistem tersebut mempermudah perwakian badan usaha untuk mendaftarkan tenaga kerjanya, namun dengan catatan yang bersangkutan belum pernah terdaftar di badan usaha lain, atau menjadi kepesertaan yang lain.

Sosialisasi penggunaan e-dabu sendiri baru dilaksanakan pada pertengahan 2016, dengan sistem yang belum sempurna. Sehingga lebih dari 30 persen badan usaha belum mengerti dan masih bingung dengan penggunaan edabu. Sistem e-dabu belum dapat membantu dalam pendaftran kepesertaan, maupun mutasi tenaga kerja dan fungsi yang lainnya, hanya dapat untuk cek jumlah kepesertaan saja, dan terkadang belum diupdate. BPJS Kesehatan mengakui bahwa sistem e-dabu masih dalam penyempurnaan. Sehingga perlu dikonfirmasi hal tersebut langsung pada pihak BPJS Kesehatan, mengatakan bahwa e-dabu merupakan sistem yang baru lahir, jadi masih perlu penyempurnaan lagi.

3. Peningkatan kerja sama dengan lembaga lain untuk memperluas cakupan kepesertaan.

BPJS Kesehatan berusaha untuk mencapai tujuannya yaitu universal coverage pada tahun 2019. BPJS Kesehatan selalu berupaya untuk 
memenuhi amanat Undang-Undang Nomor 40 tahun 2004 tentang SJSN serta Undang-Undang Nomor 24 Tahun 2011 tentang BPJS. Untuk mencapai cakupan jaminan kesehatan semesta, diperlukan sinergi yang kokoh antara BPJS Kesehatan dengan segenap pihak. Apalagi pada tahun 2016 fokus utama BPJS Kesehatan adalah optimalisasi rekrutmen Peserta Pekerja Penerima Upah (PPU) dan pengawasan kepatuhan.

\section{Pada BPJS Kesehatan KCU} Surabaya telah bekerja sama dengan PTSP untuk mengetahui pendaftaran jumlah badan usaha baru, atau perpanjangan surat ijin usaha / surat ijin operasional perusahaan untuk menjaring kepertaan baru.

\section{BPJS Kesehatan telah} meningkatkan usaha dalam perluasan kepesertaan dengan cara bekerja sama dengan lembaga perijinan (PTSP) dan adanya ARO (Assisten Relationship Officer) untuk keliling dari satu badan usaha satu ke badan usaha yang lain. Selain itu bekerja dengan dinas tenaga kerja di kota Surabaya untuk pengawasan kepesertaan badan usaha.

Pelaksanaan kerja sama dengan PTSP, dan Dinas Tenaga Kerja Surabaya dirasa efektif dalam memperluas kepesertaan untuk badan usaha. Buktinya peningkatan jumlah peserta badan usaha meningkat seiring dengan dilaksanakannya kerja sama ini.

\section{Faktor Penghambat}

1. Rendahnya dukungan dari kelompok sasaran.

Rendahnya kepercayaan Badan Usaha (BU) terhadap kualitas layanan JKN serta keengganan mematuhi alur pelayanan kesehatan berjenjang. Kualitas pelayanan menjadi ukuran untuk perluasan kepesertaan. Jika kualitas pelayanan bagus maka kepesertaan akan meningkat. Banyak badan usaha dan tenaga kerja yang masih melihat, dan merasakan pelayanan fasilitas kesehatan tingkat pertama masih banyak terdapat antrian. Pelayanan kurang ramah dan terkesan mengesampingkan pelayanan BPJS Kesehatan dari pada pelayanan kesehatan umum. Keenggenan badan usaha untuk mendaftar ke BPJS Kesehatan karena kondisi pelayanan dari faskes yang kurang baik, antrian menjadi salah satu keluhan.

Selain itu BU umumnya sudah memiliki jaminan kesehatan lain yang dianggap lebih baik dibanding JKN. Terutama bagi level manajerial perusahaan keatas. Karena pandangan untuk mengkuti program JKN adalah program jaminan kesehatan untuk 
masyarakat tidak mampu, maka perusahaan akan menggunakan jaminan kesehatan komersial yang lebih dapat memberikan pelayanan yang baik tentu juga prestisius.

Beberapa jawaban pertanyaan wawancara disimpulkan bahwa belum adanya kesadaran pribadi untuk mengikuti program JKN. Tetapi keterpaksaan karena adanya peraturan pemerintah dalam Undang-Undang yang mewajibkan untuk ikut.

2. Kurangnya peraturan untuk pengawasan kepesertaan pada Badan Usaha dan tenaga kerja.

Kurangnya peraturan untuk pengawasan kepesertaan antara badan usaha dan tenaga kerja yang dimaksud adalam implementasi potongan iuran yang sesuai dengan peraturan BPJS Kesehatan. Badan usaha akan memberlakukan potongan iuran sesukanya karena hal tersebut tidak akan diperiksa oleh pihak BPJS Kesehatan maupun dinas tenaga kerja. Selama iuran lancar dibayarkan senilai yang dilaporkan tentu tidak akan menjadi masalah jika potongan sharing tidak sesuai.

Kemudian, belum berjalannya sanksi dan penegakkan hukum bagi BU yang tidak mendaftarkan pesertanya ke BPJS Kesehatan. Meskipun demikian, sebagian besar Kantor Cabang tengah menginisiasi kerjasama dengan Pemda setempat terutama Dinas Tenaga Kerja untuk melakukan sosialisasi JKN, mensinkronisasikan daftar $\mathrm{BU}$, serta mengimplementasikan penegakan kepatuhan bagi BU yang belum mematuhi ketentuan yang ada.

3. Transparansi masih berjalan dua sisi antara BPJS Kesehatan dan Fasilitas Kesehatan.

Tidak dilibatkannya badan usaha maupun peserta penerima upah untuk memonitoring langsung pelayanan di rumah sakit. Mereka hanya disajikan data apa saja yang dikeluarkan berupa kuitansi tagihan. Peserta PPU dari badan usaha yang menjelaskan tidak ada informasi baik secara online maupun cetak mengenai prosedur pelayanan kesehatan bagi peserta yang sakit atau harus rawat inap dan membutuhkan pengawasan dokter.

4. Lemahnya peningkatan sosialisasi manfaat BPJS Kesehatan dengan badan usaha.

Minimnya jumlah staf pemasaran di kantor cabang BPJS Kesehatan. Disetiap kantor cabang BPJS Kesehatan, rata-rata hanya terdapat 1-3 orang staf pemasaran, sedangkan target yang harus dicapai sangat besar. 
Saat ini kerjasama BPJS menggencarkan fungsi ARO (Assisten Relationshio Officer) untuk lebih banyak memperluas kepesertaan. Serta kerja sama dengan disnaker untuk mengedukasi badan usaha yang belum tahu tentang manfaat mengikuti program JKN. BPJS Kesehataan juga bekerja sama dengan disnaker untuk mengadakan kunjungan rutin sebagai bentuk pengawasan, dan sosialiasi. Disnaker bersama-sama BPJS memberikan rekomendansi baik dari segi hukum, maupun manfaat untuk pemberi kerja dan pekerja itu sendiri.

\section{SIMPULAN}

Secara keseluruhan program Jaminan Kesehatan Nasional oleh BPJS Kesehatan untuk tenaga kerja di Kota Surabaya belum berhasil di implementasikan. Kebijakan yang bersifat top-down ini telah dilaksanakan telah sesuai dengan peraturan perundangperundangan, baik itu Perpres mengenai ketentuan iuran, Permenkes, mengenai pelayanan fasilitas kesehatan dan peran serta dari Dinas Tenaga Kerja dalam hal koordinasi pengawasan penjaringan kepersertaan. Masing-masing stakeholder memiliki peran yang saling berkaitan untuk mewujudkan tujuan program Jaminan Kesehatan Nasional ini. Begitu halnya BPJS Kesehatan di Kota Surabaya masih perlu banyak penyempurnaan, baik dari sistem informasi, data terintegrasi, dan perbaikan pelayanan fasilitas kesehatan khususnya bagi tenaga kerja di Surabaya. Saran yang diberikan adalah pertama, perlu ada regulasi yang mengatur tentang pengawasan lebih lanjut selain Undang-Undang Nomor 24 Tahun 2011 tentang penyelenggaraan BPJS Kesehatan pasal 19 ayat 1 dan 2 yang menyebutkan bahwa pemberi kerja wajib memungut iuran yang menjadi beban peserta dari pekerjanya dan menyetorkannya kepada BPJS, dan Pemberi kerja wajib membayar dan menyetor iuran yang menjadi tanggung jawabnya kepada BPJS untuk menghindari fraud yang merugikan tenaga kerja. Kedua, perlu peningkatan pengawasan verifikasi data dan penanganan pasien dengan inovasi sistem berbasis online, agar transparansi dan akuntabilitas dapat terpenuhi. Kedua Amnesty iuran untuk Badan Usaha Baru, untuk menarik perhatian Badan Usaha baru mendaftarkan karyawannya bagi usaha skala besar maupun usaha kecil menengah. Ketiga, Jemput bola untuk meningkatkan kuantitas kepesertaan untuk Badan Usaha. Keempat, data terintegrasi antara BPJS Kesehatan dengan BPJS Ketenagakerjaan melalui NIK (Nomor 
Induk Kependudukan) Selama ini data terintegrasi secara online untuk BPJS Kesehatan dapat diketahui dengan cara menggunakan sistem JKN-KIS dengan memasukkan NIK KTP. Jadi beberapa karyawan dapat diketahui belum terdaftar di BPJS kesehatan, meskipun telah terdaftar ke BPJS Ketenagakerjaan.

\section{DAFTAR PUSTAKA}

Abdul Wahab, S. 2005. Analisis Kebijaksanaan: Dari formulasi ke Implementasi Kebijaksanaan Negara. Jakarta: Bumi aksara

Argyris, C. 1999. On Organizational Learning. Cambridge: Blackwell

Antara News, Edisi Rabu 14 Desember 2016

Nasution, S. 2003. Metode Penelitian Naturalistik Kualitatif. Jakarta: Tarsito

Parson, Wayne. 1997. Public Policy An Introduction to The Theory and Practice of Policy Analysis. Cambridge: Edward Elyard Publishing

Samodra, Wibawa. 1994. Kebijakan Publik Proses dan Analisis. Jakarta: Intermedia

Subarsono, A.G. 2005. Analisis Kebijakan Publik. Yogyakarta: Pustaka Pelajar

Suharto, Edi. 2012. Analisis Kebijakan Publik. Bandung: Alfabeta
Sugiyono. 2003. Metode Penelitian Administrasi. Bandung: Alfabeta

Winarno, Budi. 2008. Kebijakan Publik Teori dan Proses. Jakarta: PT Buku Kita

Winarno, Budi. 2014. Kebijakan Publik: Teori, Proses dan Studi Kasus. Yogyakarta: CAPS Pusat Kajian Politik FISIP UI

Wiyoto, Budi. 2005. Implementasi Kebijakan Publik. Bandung: Griya Pustaka

Zahn, Markus. 2006. Perancangan Kota Secara Terpadu. Yogyakarta: Kanisius 